DOI: $10.25178 /$ nit.2020.2.8

\title{
Партийный архив Тувы: особенности становления и развития
}

\section{Марианна М.-Б. Харунова}

Тувинский институт комплексного освоения природных ресурсов Сибирского отделения Российской академии наук, Российская Федерация,

\section{Долаана Д. Оюн}

Национальный архив Республики Тыва, Российская Федерация,

Рамиль Ш. Харунов

Улан-Баторский филиал Российского экономического университета им. Г. В. Плеханова, Монголия

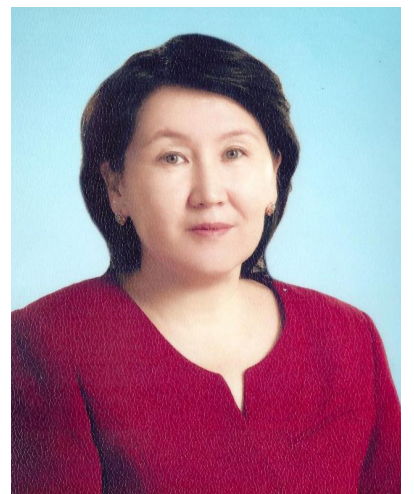

В статье представлена история партийного архива Тувинского обкома КПСС, в эволюции которого авторы усматривают три этапа: 1945-1960 г2., 1961-1991 г2., 19912017 г2.

В первые организационные годы подбирались помещение для архива, специалисты, подходящие для данной работы. Требовалось решить научно-методические вопросы по обработке, систематизации и централизации архивных материалов, а также по внутриархивной работе. На втором этапе деятельность партархива заметно улучшилась, так как организации стали руководствоваться специальными правилами, а также инструкцией по делопроизводству. На третьем этапе необходимо было обеспечить учет хранящихся документов на единой организационно-методической основе. Особую роль в успешной деятельности партархива сыграли его руководители. Дан список их имен, хронологии руководства.

Особо отмечена востребованность документов партархива в разные годы исследо-

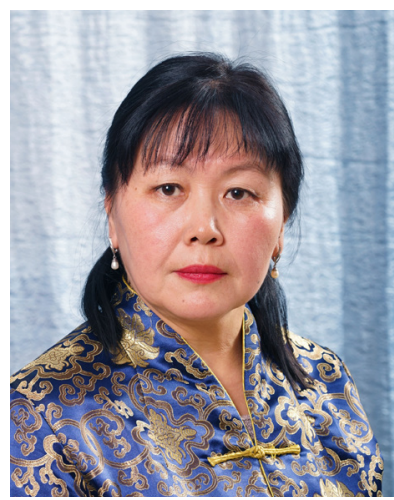
вателями - историками. Указаны имена, названия работ, защищенных диссертаций.

Ключевые слова: партийный архив; Тувинский обком КПСС; история Коммунистической партии; история Тувы; Тува; Государственный архив Республики Тыва; Национальный архив Республики Тыва; история архивного дела

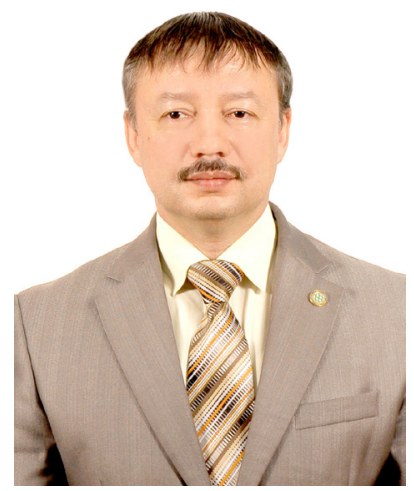

Для цитирования:

Харунова М. М.-Б., Оюн Д. Д., Харунов Р. Ш. Партийный архив Тувы: особенности становления и развития // Новые исследования Тувы. 2020, № 2. C. 120-136. DOI: www.doi.org/10.25178/nit.2020.2.8

Kharunova Marianna Monge-Bairovna, Candidate of History, Leading Research Fellow, Laboratory of regional economics, Tuvan Institute for Exploration of Natural Resources, Siberian Branch of RAS. Postal address: 117A Internatsionalnaya St., 667010 Kyzyl, Russian Federation. Tel.: +7 (913) 356-10-73.E-mail: Ondar18@mail.ru

Oiun Dolaana Demir-oolovna, Senior Officer, Department for Acquisition, Departmental Archives and Records Keeping, National Archives of the Republic of Tuva, Postal address: 91 Kechil-ool St., 667010 Kyzyl, Republic of Tuva, Russian Federation. Tel.: +7 (394-22) 5-65-44. E-mail: dolaanaoyun74@mail.ru

Kharunov Ramil Shatmuratovich, Candidate of History, Associate Professor, Interdisciplinary Department, Ulan Bator Branch, Plekhanov Russian University of Economics. Postal address: 131 Peace Avenue, Ulan Bator, 210351 Mongolia. Tel.: +976-11-450-679. E-mail: ramar33@mail.ru 


\title{
The Archives of the Communist Party in Tuva: Its Rise and Development
}

\author{
Marianna M.-B. Kharunova \\ Tuvinian Institute for Exploration of the Natural Resources, Siberian Branch of RAS, Russian Federation, \\ Dolaana D. Oiun \\ National Archives of the Republic of Tuva, Russian Federation, \\ Ramil Sh. Kharunov \\ Ulan Bator Branch, Plekhanov Russian University of Economics, Mongolia
}

\begin{abstract}
The paper presents the history of the Archives of Tuva Oblast Committee of Communist Party of the Soviet Union (CPSU). The authors have sketched three periods in its development: 1951-1959, 1960-1991, and 1991-2017.

In the early years after the set-up of the Communist party structures in Tuva, it was highly important to find the adequate premises and to recruit appropriate staff for managing the Archives. It was necessary to solve research and methodological questions of processing, systematizing and centralizing archival materials, as well as to organize work within the Archives. The second period in the history of the Archives witnessed a considerable improvement since the organizations began to be guided by specific work codes and records management instructions. The third period's priority was to set management of the Archives on a uniform organizational and methodological basis. A special role in the archives' achievements belonged to its managers. Provided is the list of their names and chronology of their leadership.

The authors emphasize that documents preserved at the Archives of the Communist Party of Tuva over many years have enjoyed a high demand by historians. Also listed in the article are their names, titles of contributions and defended dissertations.
\end{abstract}

Keywords: party archive; Tuva Oblast Committee of CPSU; history of Communist Party; history of Tuva; Tuva; State Archives of the Republic of Tuva; history of archiving

\section{For citation:}

Kharunova M. M.-B., Oiun D. D. and Kharunov R. Sh. The Archives of the Communist Party in Tuva: Its Rise and Development. The New Research of Tuva, 2020; 2: 120-136. (In Russ.). DOI: www.doi.org/10.25178/nit.2020.2.8

\section{Введение}

Коммунистическая партия оказала большое влияние на социально-экономическое развитие советского общества, в том числе на Туву, вошедшую в состав СССР в 1944 г. Вопросы политики, экономики, образования, здравоохранения, науки, культуры и пр. нашли свое отражение в решениях, постановлениях и отчетах, хранящихся в фондах партийного архива Тувинского обкома КПСС, научная и социальная значимость которых бесспорна для изучения прежде всего истории Тувы.

Очевидна актуальность научного осмысления не только документов, содержащихся в фондах партийного архива, но его деятельности, более глубокого изучения вопросов его становления, развития и перспектив, кадрового и материально-технического обеспечения, комплектования фондов, сохранности документов, цифровизации, источниковедческого анализа архивных документов и др. вопросов архивоведения.

Отдельные аспекты истории и функционирования партийного архива изучались и обсуждались на научно-практических конференциях, материалы которых опубликованы в сборниках (Доклады и сообщения ... , 2000; Материалы научно-практической ... , 2008; Мунге, 2018). Так, например, О. В. Аньшина отметила работу бывшего партийного архива с держателями личных фондов (Аньшина, 2000). Н. Д. Болдур-оол рассмотрела вопрос интеграции фондов бывшего партийного архива в систему государственного учета документов и в систему государственного учета документов Центрального государственного архива Республики Тыва (Болдур-оол, 2000). С. К. Гущина изложила деятельность архива и представила обзор некоторых его фондов (Гущина, 2000). Н. Е. Михайлова исследовала во- 
просы отбора и комплектования документов общественно-политических организаций республики (Михайлова, 2000). Д.Д. Оюн обобщила сведения об образовании центра по хранению документов партии и общественных организаций, его фондах, составе документов (Оюн, 2008). Б. Ю.Сандак представил работу Центра архивных документов партий и общественных организаций с общественными организациями, их роль в комплектовании Архивного фонда Республики Тыва (Сандак, 2008).

Деятельность партийного архива также нашла отражение в обзорных статьях Д. И. Чыдыма (Чыдым, 2000), Т. С. Саая (Саая, 2000), Б. В. Мунге, (Мунге, 2018), посвященных в целом развитию Архивной службы в Туве.

В нашей статье мы впервые рассмотрим историю становления партийного архива Тувинского обкома КПСС от момента его становления до реорганизации в систему Государственного архива Республики Тыва, выделим этапы развития, особенности комплектования и содержания его основных фондов на каждом из них: 1945-1960 гг., 1961-1991 гг., 1991-2017 гг.

Источниковой базой для работы стали документы фонда «Партийный архив Тувинского обкома КПСС» в Национальном архиве Республики Тыва (Государственном архиве Республики Тыва, ГА РТ)1. Нами проанализированы отчеты, планы работы партархива, паспорта архива за 1953-1991 гг., справки о работе архива и переписка с партийными и другими организациями. Материалы личных дел фонда «Тувинский обком КПСС» позволили получить сведения о заведующих партархива, в разные годы трудившихся в нем.

\section{Становление партийного архива и его развитие в 1945-1960 г2.}

Все архивные материалы ВКП(б) в Туве с 1945 г. находились в отделах обкома, райкомах и горкоме ВКП(б) и ВЛКСМ. Архивные материалы Центрального Комитета Тувинской народно-революционной партии (ЦК ТНРП) находились в архиве УМВД по Тувинской автономной области.

В 1951 г. по решению бюро Тувинского обкома ВКП(б) при обкоме организуется областной партийный архив, хотя штат и смета архива были отпущены ЦК партии еще после вхождения Тувы в состав Советского Союза в 1944 г. В партархив из госархива были переданы все документы партийных и комсомольских организаций, что определялось требованиями времени (Мунге, 2018: 6). Первым заведующим партийным архивом Тувинского обкома ВКП(б) был назначен Мындрима Сат Шангыроолович (ГА РТ, ф.-П. 2, оп. 1, д. 470, л. 178).

Партийный архив Тувинского обкома КПСС в момент своего образования не имел помещения под хранилище архива. Поэтому в течение 1951-1952 гг. проводились только подготовительные работы по систематизации и обработке архивных материалов на местах. И только в феврале 1953 г. временно было выделено помещение под хранилище в здании УМВД в г. Кызыле по ул. Ленина д. 18, общей площадью $12 \mathrm{~m}^{2}$, т. е. $3 \times 4$ м. (ГА РТ, ф.-п. 42, оп. 1, д. 37, л. 4).

В начале своей деятельности партархив работал в составе 2-х человек, в соответствии со штатным расписанием: заведующий С. Ш. Мындрима и архивотехнический сотрудник Б. Б. Борбак-оол (ГА РТ, ф.-п. 42, оп. 1, д. 40, л. 2). В 1954 г. штат увеличился до 3-х человек, а в последующие годы - до 5 человек.

На долю первого заведующего партархивом Тувинского обкома КПСС выпали первые самые трудные организационные годы по приведению в порядок партийных фондов и других не систематизированных материалов. Имелось много неясностей по обработке, систематизации и централизации архивных материалов, а также по внутриархивной работе. В хранилище, где был размещен архив, не было условий для нормальной работы: не было кабинета, где можно было принимать архивные материалы и заниматься научно-технической обработкой архивных материалов, а также справочной работой.

28 апреля 1953 г. заведующий пишет письмо в обком КПСС. Оно было рассмотрено на бюро обкома КПСС и 4 мая 1953 г. было принято постановление обкома КПСС «О сдаче архивных материалов ТНРП и КПСС в партийный архив», по которому завотделами и секторами обкома КПСС обязаны были сдать архивные материалы ЦК ТНРП с начала ее деятельности по 1944 г. включительно и обкома КПСС с 1945 по 1950 г. в обработанном, разобранном (систематизированном) и описанном виде (ГА РТ, ф.-п. 2, оп. 1, д. 641, л. 199).

${ }^{1}$ В связи с тем, что переименование архива пришлось на период предпечатной подготовки статьи (7 апреля 2020 г.) далее мы сохраняем в тексте старое название "Государственный архив Республики Тыва" и аббревиатуру "ГА РТ". ped.

Editors' note: Since the Archives was renamed while editorial work on the article was already under way (April 7, 2020), we have preserved at some places the institution's old name - "State Archives of the Republic of Tuva". 
Особое внимание партархив уделял именно инструктированию работников райкомов и горкомов партии и комсомола. Для улучшения работы были переведены на тувинский язык и разосланы во все районы и горкомы КПСС «Правила хранения и обработки документальных материалов в райкомах и горкомах КПСС и ВЛКСМ». Перевод этих правил был утвержден секретариатом обкома КПСС 30 августа 1953 г.

После оборудования хранилища были приняты архивные материалы ЦК ТНРП за 1921-1944 гг., однако в необработанном виде, в россыпи, отдельными листами. Документальные материалы ЦК ТНРП подвергались научно-технической обработке в течение нескольких лет. Эта работа была начата в 1954 г. (ГА РТ, ф.-п. 42, оп. 1, д. 76, л. 12). Часть архивных материалов была на монгольском языке, и поэтому для обработки и систематизации документов привлекались специалисты, владеющие тувинским, монгольским и русским языками. В их числе были поэты, прозаики, драматурги, переводчики А. Б. Сарыг-оол, Б. Д. Ховенмей (ГА РТ, ф.-п. 42, оп. 1, д. 89, л. 2), О. К. Саган-оол, С. Т. Танов (ГА РТ, ф.-П. 42, оп. 1, д. 118, л. 9).

В фонде «Центральный комитет Тувинской народно-революционной партии (ЦК ТНРП)» (3336 ед. хр. за 1882, 1911, 1913, 1916-1944 гг.) хранятся материалы съездов, конференций, пленумов ТНРП, заседаний Президиума и политбюро ЦК ТНРП, в которых рассматривались вопросы внешней и внутренней политики ТНРП и ТНР, а также материалы по международным политическим и экономическим связям, взаимодействию с Коминтерном, ЦК КПСС и Советским Правительством. В фонде содержатся:

документы об образовании кожуунов;

сведения о руководстве партии;

правительства ТНР и Революционого союза молодежи; протоколы партийных ячеек;

кожуунных комитетов партии;

тексты Конституций ТНР;

программы и уставы ТНРП;

материалы центральной комиссии по сбору подарков Красной Армии;

вопросы, связанные с отправкой добровольцев на фронт;

сведения о партийной организации первого тувинского добровольческого отряда;

развернутые доклады о развитии разных отраслей народного хозяйства ТНР в 1944 г.;

географические сведения ТНР и характеристики хошуунов в 1944 г.;

списки аратов-скотоводов, руководящих работников ТНР и советских специалистов,

представленных к награждению орденами и медалями СССР от 30.06.1944 г.;

личные дела номенклатурных работников.

Учитывая содержание документов, данный фонд постоянно востребован учеными, исследователями, аспирантами, студентами и преподавателями научных и образовательных учреждений республики и других регионов страны.

Графическая основа документов: на старомонгольской письменности - 737 ед. хр., написанные латинизированным алфавитом - 1007 ед. хр. на тувинском языке, на кириллице - 1592 ед. хр. на тувинском и русском языках.

В 1954 г. архив провел ряд мероприятий по инструктированию и оказанию помощи райкомам партии и комсомола, а также по приему документов. В течение данного года были приняты документы 5 райкомов КПСС (Дзун-Хемчикского, Каа-Хемского, Овюрского, Тандинского, Тес-Хемского) с общим количеством ед. хр. - 1806, в т. ч. от 43 первичных организаций - 152 ед. хр. (ГА РТ, ф.-П. 42, оп. 1, д. 51, л. 9). Партархив стал уделять особое внимание при приеме документов их целостности. При проверке в райкомах и первичных организациях партии были обнаружены недостатки общего характера по хранению документов, в частности документы не были упорядочены, хранились в столах, шкафах.

На 1 января 1955 г. в партийном архиве Тувинского обкома имелось 13 фондов: ЦК ТНРП, Тувинского обкома КПСС, Тере-Хольского и Тес-Хемского хошкомов ТНРП, Тандинского, Монгун-Тайгинского, Каа-Хемского, Кызылского, Эрзинского, Овюрского, Дзун-Хемчикского, Тере-Хольского и Тес-Хемского райкомов партии - 4347 ед. хр. (ГА РТ. Ф.-П. 42, Оп. 1, д. 46, л. 2-3, д. 51, л. 13-17).

В фонде «Тувинский обком КПСС» хранится - 11422 ед. хр. за 1944-1991 гг. Документы этого фонда включают в себя протоколы партийных конференций, пленумов, заседаний бюро, секретариата обкома ВКП(б) и КПСС, партактивов, справки, информации в вышестоящие партийные органы, материалы 
комиссии партийного контроля при обкоме КПСС. Документы широко характеризуют работу партийных органов республики по развитию промышленности, сельского хозяйства, капитального строительства, культуры, науки, а также по улучшению материального благосостояния жителей республики (Гущина, 2000: 37).

В данном фонде имеются личные дела работников обкома КПСС, персональные дела и другие материалы, относящиеся к документам личного состава.

Фонды хошкомов ТНРП состоят из постановлений и указаний ЦК ТНРП, постановлений пленумов и бюро хошкомов, отчетов, материалов по сбору подарков для Красной Армии, а также имеются анкеты и личные дела членов партии.

Фонды райкомов КПСС содержат протоколы конференций, пленумов и заседаний бюро райкомов партии, указаний обкома КПСС, статотчеты и финансовые документы, личные дела членов ВЛКСМ и другие материалы, относящиеся к документам личного состава.

Основные сложности в работе партархива заключались, во-первых, в отсутствии помещения для хранилища. Хотя в 1954 г. было дополнительно выделено в здании УМВД полуподвальное помещение под хранилище $25 \mathrm{~m}^{2}$ (+ рабочие комнаты на 1 этаже $-12 \mathrm{~m}^{2}$ ), но оно удовлетворяло потребностям партархива примерно только на год. Во-вторых, по прежнему сложным оставался кадровый вопрос, нужны были специалисты, которые могли профессионально заниматься архивным делом в соответствии с требованиями.

Необходимо отметить, что в 1956 г. для усовершенствования деятельности партийных архивов был разработан «Примерный перечень типовых документальных материалов партийных органов и первичных партийных организаций, с указанием сроков хранения», который служил «руководством при отборе документов партийных органов и организаций на хранение и уничтожение». В партийные архивы не принимались документы, имеющие значение только для текущей работы ${ }^{1}$.

В 1957 г. партархив Тувинского обкома КПСС переехал из здания УМВД в здание УКГБ при Совете Министров СССР по Тувинской автономной области и получил новое хранилище и рабочий кабинет. А в 1958 г. архиву дополнительно выделяется 1 комната под хранилище с общей площадью 12 м² $^{2}$ (ГА РТ, ф.-п. 42, оп. 1 , д. 88 , л. 13).

С 1953 г. по январь 1958 г. партархивом приняты документальные материалы ЦК ТНРП за 1923-1944 гг., отделов и секторов обкома КПСС, 16 райкомов партии и первичных парторганизаций, партшколы, политотдела «Тувзолото» за 1945-1955 г. Всего за этот период принято 12748 дел (ГА РТ, ф.-п. 42, оп. 1, д. 76, л. 6).

Так как в основном принимались документы ЦК ТНРП, то в первую очередь партархив ставил задачу научно-технической обработки документальных материалов, которая была завершена к концу 1957 г. В письме заведующего партархива секретарю обкома КПСС от 15 марта 1958 г. докладывалось об окончании научно-технической обработки документальных материалов ЦК ТНРП и указывалось число обработанных дел - 1860. На них были составлены описи в 3-х экземплярах по годам, в пределах годов - по важности документов. Кроме того, выделены 124 дела, не подлежащих хранению. Далее указано на то, что не оказалось некоторых важных документов, касающихся создания и деятельности ТНРП (ГА РТ, ф.-П. 42, оп. 1, д. 89, л. 1-2).

На 1 января 1959 г. в партархиве Тувинского обкома КПСС числилось 13913 ед. хр., всего фондов 30 (в том числе 29 партийных, 1 - комсомольский) (ГА РТ, ф.-п. 42, оп. 1, д. 88, л. 9).

Испытывая большие трудности, не имея вначале даже помещения под архивные документы, сотрудники партархива организовали его деятельность, сбор и приведение в порядок полученных материалов, их экспертизу и обработку. Во время командировок они оказывали практическую помощь сотрудникам партийных и комсомольских органов по обработке, систематизации, сдаче, а также по хранению документов в райкомах КПСС и ВЛКСМ. В это время началась научно-техническая обработка документов и устанавливалось тесное взаимодействие с организациями и учреждениями по вопросам оформления и сохранности документов, поступающих в фонды партийного архива.

\footnotetext{
${ }^{1}$ Васильева А. Г. Использование документов КПСС: теоретические аспекты [Электронный ресурс] // Пермский государственный архив социально-политической истории. URL: http://https://www.permgaspi.ru/publikatsii/ stati/ispolzovanie-dokumentov-kpss-teoreticheskie-aspekty.html (дата обращения: 15.03.2020).
} 


\section{От количества к качеству: деятельность партийного архива в 1961-1991 22.}

К 1961 г. райкомы партии при обработке своих документов и приведении их в порядок уже руководствовались вышеназванным «Примерным перечнем» 1956 г. (ГА РТ, ф.-П. 42, оп. 1, д. 65, л. 2-55). Это имело большое положительное значение в улучшении делопроизводства в партийных органах, сохранности и сдаче документов в партархив.

В 1961 г. от партийных и комсомольских органов и организаций всего принято 8986 ед. хр. На основании распоряжения Архивного отдела УВД Тувоблисполкома от 8 июля 1961 г. № (б/н) Госархив Тувинской Автономной Области передал в партархив материалы без описей общим количеством 573 ед. хр. на монгольском языке за 1922-1931 гг., для выявления и научно-технической обработки которых привлекались монголоведы, работники партийного и государственного архивов (ГА РТ, ф.-П. 42, оп. 1, д. 118, л. 6). В результате проведенной работы и осуществленных переводов с монгольского на тувинский язык было сформировано 571 дело. Если по описи в фонде ЦК ТНРП прежде было 216 ед. хр., то теперь их стало 787 ед. хр. (ГА РТ, ф.-п. 42, оп. 1, д. 120, л. 8).

В том же 1961 г. партархиву были выделены в здании КГБ при Совете Министров Тувинской АССР:

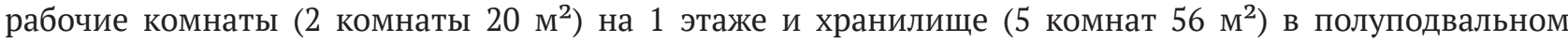
помещении, которое не было приспособлено для хранения документов, так как в нем не было вентиляции. Оно располагалось по адресу: г. Кызыл, ул. Красных Партизан, д. 31. Степень загруженности хранилища документами составляла примерно 85\%. Данное помещение не удовлетворяло требованиям хранения документов и по объему (ГА РТ, ф.-п. 42, оп. 1, д. 118, л. 10).

В какой-то мере партархиву должно было помочь то, что в 1965 г. был принят «Перечень документальных материалов партийных органов и первичных организаций, подлежащих хранению в партийных архивах», который был призван «способствовать созданию меньшего по объему, но полноценного по содержанию комплекса документов по истории партии и советского общества» 1 . Партийные архивы должны принимать на хранение документальные материалы преимущественно производственных первичных партийных организаций, крупных или ведущих учреждений науки, культуры, торговли, здравоохранения, органов государственной власти.

В 1974 г. из госархива Совета Министров Тувинской АССР были переданы в партархив документы, относящиеся к деятельности ЦК и районных комитетов ТНРП на монгольском языке (1923-1929 гг.). Документы поступили не обработанные, большая часть из них, к сожалению, россыпи, листы.

На 1 января 1975 г. в партархиве насчитывалось 187 фондов, 53689 ед. хр. (ГА РТ, ф.-П. 42, оп. 1, д. 200, л. 2). Новые фонды были сформированы из документов Кызыльского горкома ВЛКСМ, 16 райкомов ВЛКСМ, 9 парткомов, 126 первичных партийных организаций. Также появились такие фонды, как: «Политотдел военкомата Тувинской АССР», «Партийный архив Тувинской АССР», «Тоджинский хошунный комитет ТРСМ», «Районное бюро РКП(б) и ВКП(б) в ТНР (Урянхае)», личный фонд «С. К. Тока», видного партийного и государственного деятеля Тувы.

С 1970 г. партархив размещался в подвальном помещении Дома политического просвещения (ДПП), построенного в 1969 г. (ГА РТ. Ф.-П. 2, Оп. 1, д. 2321, л. 47). Он занимал 4 комнаты: хранилище 178 м², 3 подсобные комнаты с общей площадью 25,6 м² , на 2-м этаже 2 комнаты общей площадью 45 м $^{2}$, где занимались работники партархива. Архив по-прежнему не имел специального читального зала. Исследователи занимались в рабочих комнатах работников архива (ГА РТ, ф.-П. 42, оп. 1, д. 201, л. 59).

На 1 января 1981 г. в партархиве числилось 64666 ед. хр., 297 фондов (ГА РТ, ф.-П. 42, оп. 1, д. 200, л. 2). На постоянное хранение были сданы документы горкомов, райкомов партии и комсомола. Заметно улучшилось их физическое состояние и качество оформления при сдаче. Количество фондов увеличилось в основном за счет приема документов 102 первичных партийных организаций и 8 парткомов.

Проводится работа по уточнению фондовой принадлежности документов. Из фонда обкома КПСС выявляется 1467 дел советских, хозяйственных работников, они передаются в архив Совета Министров Тувинской АССР, так как признаны не относящимися к фондам партийного архива. Также из этого же фонда выделены отдельно хранящиеся 442 дела по приему в кандидаты в члены КПСС (ГА РТ, ф.-П.

\footnotetext{
${ }^{1}$ Васильева А. Г. Использование документов КПСС: теоретические аспекты ...
} 
42, оп. 1, д. 201, л. 51), но которые остались в партархиве. На бюро обкома КПСС скорректированы и утверждены списки первичных партийных организаций, документы которых подлежат постоянному хранению. Проделана работа по совершенствованию фонда обкома партии и ряду райкомов по упорядочиванию приема дел по единой описи от всех отделов, в которых были нарушены структурнохронологические принципы.

В 1977 г. из государственного архива по акту получены на хранение в партархив документы ЦК ТНРП и ЦК ТРСМ на монгольском языке, из них сформированы дела, определены их фондовые принадлежности. Всего поступило на хранение таких дел в фонд ЦК ТНРП - 260, в фонд ЦК ТРСМ - 160. Пополнился новыми документами фонд «Партийный архив Тувинского обкома КПСС». Было собрано 38 воспоминаний ветеранов партии и комсомола, материалы Конституции Тувинской АССР (ГА РТ, ф.-п. 42, оп. 1, д. 201, л. 52).

Партархив стал обращать внимание партийных и комсомольских органов на сохранность и правильное оформление документов, имеющих научное и практическое значение, что способствовало созданию более полноценного по содержанию архивного фонда.

Вместе с тем решался вопрос по улучшению условий хранения документов. Архивохранилище находилось в подвальном помещении, где не был исключен риск затопления. Для обеспечения сохранности и улучшения условия хранения документов ставился вопрос перед руководством обкома КПСС.

Строительство нового типового здания партархива в перспективе не предусматривалось, а планировалась пристройка к зданию существующего здания обкома КПСС, где предполагалось разместить партархив на 150-200 тыс. ед. хр. (ГА РТ, ф.-п. 42, оп. 1, д. 201, л. 54).

На 1 января 1989 г. в партархиве уже имелось 347 фондов, 80296 ед. хр. (ГА РТ, ф.-п. 42, оп. 1, д. 269, л. 19). Появились новые фонды: «Издательство Тувинского обкома КПСС», «Коллекция фотодокументов партийного архива Тувинского обкома КПСС», «Партком совхоза “1 мая” Тоджинского района», «Редакция газеты “Молодежь Тувы”», «Редакция газеты “Тыванын аныяктары”», а также 46 фондов первичных партийных организаций.

В течение 1989-1990 гг. сотрудники партархива, исходя из задач архивных учреждений, проводили работу по обеспечению сохранности архивных документов, пополнению новыми материалами, учету и обработке. Основное внимание уделялось устранению недостатков, отмеченных в результате обследования Центральным партийным архивом Института марксизма-ленинизма при ЦК КПСС в 1986 г., в числе которых указывались следующие: использование устаревших бланков учетных форм; ошибки при экспертизе научной и практической ценности документов; состав документов, принимаемых от партийных и комсомольских органов, не в полной мере соответствовал требованиям «Перечня документов партийных органов и первичных организаций, подлежащих сдаче в партийные архивы», разработанному в 1984 г. ЦПА ИМЛ при ЦК КПСС»; не велась картотека учета исследователей, а также работа по разработке систематического каталога по основным фондам (ГА РТ, ф.-П. 42, оп. 1, д. 253, л. 4-12).

В общем объем принимаемых дел, наряду с традиционными видами документов (протоколами конференций, пленумов и бюро), стали поступать протоколы различных общественно-политических мероприятий (ГА РТ, ф.-п. 42, оп. 1, д. 273, л. 10). В этот период вся учетная документация приводилась в полное соответствие с основными формами и требованиями «Правил работы партийных архивов обкомов, крайкомов партии, институтов истории партии - филиалов ИМЛ при ЦК КПСС» (Правила работы ..., 1980).

Анализ годовых отчетов показывает, что объем поступления документов увеличивался ежегодно (см. таб. 1).

Так, мы видим, что за 35 лет - с 1954 по 1989 гг. - деятельности партархива количество его фондов увеличилось в 43 раза, а количество единиц хранения - на 77755 штук. На данном историческом этапе Тувинская автономная область была преобразована в Тувинскую АССР. Изменение политического статуса Тувы не влияло на правило работы партийного архива, который руководствовался вышеупомянутыми общими документами, разработанными Центральным партийным архивом Института марксизма-ленинизма при ЦК КПСС.

Архив систематически пополнялся новыми материалами. Основными источниками комплектования являлись документы партийных и комсомольских органов республики и их организаций. Первое место по значимости принадлежало фонду документов областного комитета партии, поэтому они 
поступали в архив ежегодно по истечении определенного срока хранения. Районные комитеты партии сдавали свои архивы по мере их упорядочивания.

Таблица 1. Динамика роста количества фондов и единиц хранения в Партийном архиве Тувинского обкома КПСС (1954-1989 г2.)

Table 1. Growth of the fonds and archival units in the Communist Party Archive of the Tuvan Regional Committee of the CPSU, 1954-1989.

\begin{tabular}{|l|l|c|c|l|}
\hline \multicolumn{1}{|c|}{ № } & \multicolumn{1}{|c|}{ Период } & $\begin{array}{c}\text { Кол-во } \\
\text { фондов }\end{array}$ & Кол-во ед. хр. & \multicolumn{1}{c|}{ Основание } \\
\hline 1 & На 01.01.1954 г. & 8 & 2541 & ГА РТ, ф.-п. 42, оп. 1, д. 51, л. 13. \\
\hline 2 & На 01.01.1959 г. & 30 & 13913 & ГА РТ, ф.-п. 42, оп. 1, д. 88, л. 9. \\
\hline 3 & На 01.01.1962 г. & 37 & 29170 & ГА РТ, ф.-п. 42, оп. 1, д. 105, л. 2. \\
\hline 4 & На 01.01.1975 г. & 187 & 53689 & ГА РТ, ф.-п. 42, оп. 1, д. 200, л. 2. \\
\hline 5 & На 01.01.1981 г. & 297 & 64666 & ГА РТ, ф.-п. 42, оп. 1, д. 200, л. 2. \\
\hline 6 & На 01.01.1989 г. & 347 & 80296 & ГА РТ, ф.-п. 42, оп. 1, д. 269, л. 19. \\
\hline
\end{tabular}

На наш взгляд, ежегодное увеличение объема документов быстрыми темпами объясняется следующими факторами: во-первых, в формировании и сдаче их в архив оказывали большую методическую помощь сами сотрудники партархива, закрепленные за конкретными райкомом или парторганизацией. Они выезжали на места, помогали приводить в порядок материалы, составляли описи. Документы поступали на хранение в партархив уже в обработанном виде. Во-вторых, конечно, повлияло элитное положение самого партийного органа. Ведь тогда любое инструктивное письмо обкома партии для райкомов и парторганизаций являлось жестким документом, от выполнения которого никто не мог уклониться. В-третьих, финансовое состояние самого архива, так и сотрудников, их привилегированное положение всегда позволяли решать многие вопросы без проблем. Например, оплачивались командировки сотрудников в районы, перевозка документов и пр. В-четвертых, как известно, источниками комплектования являлись только партийные и комсомольские организации, в деятельности которых формировалась новейшая документация с налаженным делопроизводством.

Анализ отчетов, рассмотренных за 1953-1991 гг., показывает, что работа по использованию материалов в научно-исследовательской, публикационной и пропагандистской работе партархива Тувинского обкома КПСС на первых порах велась недостаточно. Так, в первые годы его работы исследователей было немного, в среднем 2-5 человек. Например, в 1956 г. в партийном архиве работал один исследователь - научный сотрудник ТНИИЯЛИ, диссертант Ю. Л. Аранчын над темой «Тува в годы Великой Отечественной войны» (Аранчын, 1955), ему было выдано только 7 ед. хр., так как документы ЦК ТНРП данного периода не были еще обработаны (ГА РТ, ф.-п. 42, оп. 1, д. 67, л. 6). В 1958 г. - 2 исследователя: Х. М. Сейфуллин, кандидат исторических наук, зам. директора ТНИИЯлИ, по теме: «История Тувы в период 1921-1944 гг.», в этом же году вышла его работа «История Тувы. Краткий очерк» (Сейфуллин, 1958). Другим исследователем был М.Б. Кенин-Лопсан, редактор Тувинского книжного издательства, работавший по теме «Очерки Тувинской советской литературы», который также впоследствии стал выдающимся ученым, кандидатом, затем доктором исторических наук (Кенин-Лопсан, 1982, 1996).

В 1960 г. в партархиве работали 4 исследователя, в 1961 г. - 5 человек, в 1962 г. - 4. Исследователей интересовали документы по истории Тувы и областной парторганизации.

Уже в 1963 г. в партархиве работали 10 исследователей, трое из них приезжие: из г. Ленинграда, г. Иркутска, г. Улан-Удэ. Работали они по разным темам: «Проблемы некапиталистического пути развития народов Сибири и МНР», «Дружба народов СССР - источник могущества Советского государства и его Вооруженных сил», «Тувинская облпарторганизация за социалистическое развитие сельского хозяйства Тувы (1944-1960 гг.)», «Рабочий класс Тувы», «Вклад Тувы в разгром фашистской Германии», «50 лет г. Кызылу». 
С каждым годом масштабы использования документов в научных целях расширялись. Так, в 1976-1980 гг. партийный архив обслужил 94 исследователя. Всего было 373 посещения, выдано из хранилища 4234 ед. хр. (ГА РТ, ф.-п. 42, оп. 1, д. 201, л. 56).

В 1988-1989 гг. в партархиве работали 22 исследователя. Так, Л. Ш. Ондар, аспирантка Московского областного педагогического университета изучала документы по теме: «Партийное руководство комсомолом в борьбе за строительство социализма в Советской Туве (1944-1987 гг.)», чуть позже она защитила кандидатскую диссертацию по уточненной теме: «Социально-экономическое и культурное развитие Республики Тува в составе России, 1944-1993 гг.». (Ондар, 1994). С. А. Кушнарев, аспирант Иркутского государственного университета, рассматривал «Деятельность партийных организаций Восточной Сибири по развитию научно-технического творчества молодежи в годы XI-XII пятилеток» (публикацию или диссертацию этого автора по данной теме не удалось обнаружить).

На основе документов партархива и других материалов кандидатом исторических наук О. Ю. Толгар-оолом (Толгар-оол, 1967) написана исследовательская работа «Об отношении партийных организаций Тувы к репрессиям 1937-1938 и начала 50-х годов». Кандидат исторических наук, доцент 3. Ю. Доржу работала над монографией «Деятельность Тувинской областной организации КПСС по повышению социальной активности женщин» (Доржу, 1979) (ГА РТ, ф.-П. 42, оп. 1, д. 273, л. 8, 14). Старший научный сотрудник ТНИИЯЛИ Н. М. Моллеров работал над кандидатской диссертацией по теме «Организация советских граждан в Туве и их роль в укреплении советско-тувинских отношений (1917-1944 гг.)». В дальнейшем он защитил кандидатскую диссертацию (Моллеров, 1990) и опубликовал книгу (Моллеров, 1989).

Разрешение на работу с документами партархива выдавалось секретарем или заведующим отделом пропаганды и агитации, допуск исследователей к документам партархива в период до августа 1991 г. был ограниченным (ГА РТ, ф.-П. 42, оп. 1, д. 201, л. 56).

Члены авторского коллектива, работавшие в 2008-2016 гг. над III томом «Истории Тувы», собирали информацию для своих разделов. В его создании приняли участие ученые из разных научных учреждений Тувы и России: Тувинского института гуманитарных и прикладных социально-экономических исследований, Института истории Сибирского отделения Российской академии наук, Тувинского государственного университета, Тувинского института комплексного освоения природных ресурсов Сибирского отделения Российской академии наук, Национального музея им. АлданМаадыр Республики Тыва, Национальной библиотеки им. А. С. Пушкина Республики Тыва (Очур, 2017: 202).

Современные исследователи также продолжают обращаться к партийным документам. Как справедливо отметил А. К. Канзай в своей статье, посвященной партийным органам и общественным организациям ТНР в годы Великой Отечественной войны: «Из всех этих материалов четко видна огромная разъяснительная, политико-воспитательная и организаторская работа партийно-государственных органов: ЦК ТНРП, Малого Хурала трудящихся и Совета Министров ТНР, их местных подразделений и общественных организаций» (Канзай, 2017: 27).

Кроме выдачи справок лицам, учреждения партархива выполняли работу по выявлению и подборке документов по тем или иным вопросам для партийных, комсомольских органов и других учреждений. Они в партархиве в основном запрашивали материалы для составления сборников, об истории создания партийных и комсомольских органов, о важных событиях в деятельности ТНРП и ТРСМ, об отдельных их руководителях. Подборка документов, публикация статей, очерков в журналах, газетах также является одной из форм использования архивных документов.

Одной из основных форм использования документов архива является наведение справок и исполнение тематических запросов, поступающих от частных лиц, учреждений и организаций. Характеры запросов бывает разным, но в основном о прошлой партийной принадлежности, о наложении партийных взысканий, о трудовой деятельности и т. д.

Таким образом, партийный архив Тувинского обкома КПСС являлся учреждением, обособленным от единой системы Государственной архивной службы СССР. Он существовал самостоятельно в плане комплектования, хранения и использования документов. Следует отметить, что его деятельность была односторонней: в основном архив занимался комплектованием документальных материалов органов КПСС, партийных и комсомольских организаций, учетом и обеспечением их сохранности. Архив, его фонды и документы, по существу, находились на закрытом хранении, подавляющее большинство их имели грифы. 


\section{Руководители партийного архива}

За всю историю деятельности партахива его возглавляли следующие специалисты:

1951-1965 гг. - Мындрима Сат Шангролович, о котором выше уже было сказано;

1965-1967 гг. - Чимба Александр Маныгеевич (ГА РТ, ф.-п. 2, оп. 2, д. 1329, л. 28);

1967-1972 гг. - Ховенмей Бай-Кара Дамчаевич (ГА РТ, ф.-п. 2, оп. 2, д. 1480, л. 22);

1972-1976 гг. - Аракчаа Кыргыс Тадаевич (ГА РТ, ф.-п. 2, оп. 2, д. 1666, л. 41);

1976-1984 гг. - Баян Санаа Шондаанович (ГА РТ, ф.-п. 2, оп. 2, д. 2748, л. 12);

1985-1990 гг. - Кол Ажылчын Даржаевич (ГА РТ, ф.-п. 2, оп. 2, д. 2606, л. 15);

1990-1997 гг. - Евтешин Василий Миронович (ГА РТ, ф.-п. 2, оп. 2, д. 2590, л. 37);

1998-2000 гг. - Гущина Светлана Константиновна (ГА РТ, ф.-п. 12, оп. 2, д. 38, л. 7-8);

1997-1998 гг., 2000-2003 гг. - Монгуш Базыр Давааевич (ГА РТ, ф. 12, оп. 2, д. 33, л. 16; д. 37, л. 14; д. 38, л. 7 ; д. 45, л. 6).

Каждый из них внес свой вклад в организацию работы партархива Тувинского обкома КПСС.

Короткие биографические справки об этих людях, хранящиеся в архивных документах, как например нижеприведенная о С. Ш. Мындрима, свидетельствуют об удивительном трудолюбии этих людей и многогранности их талантов.

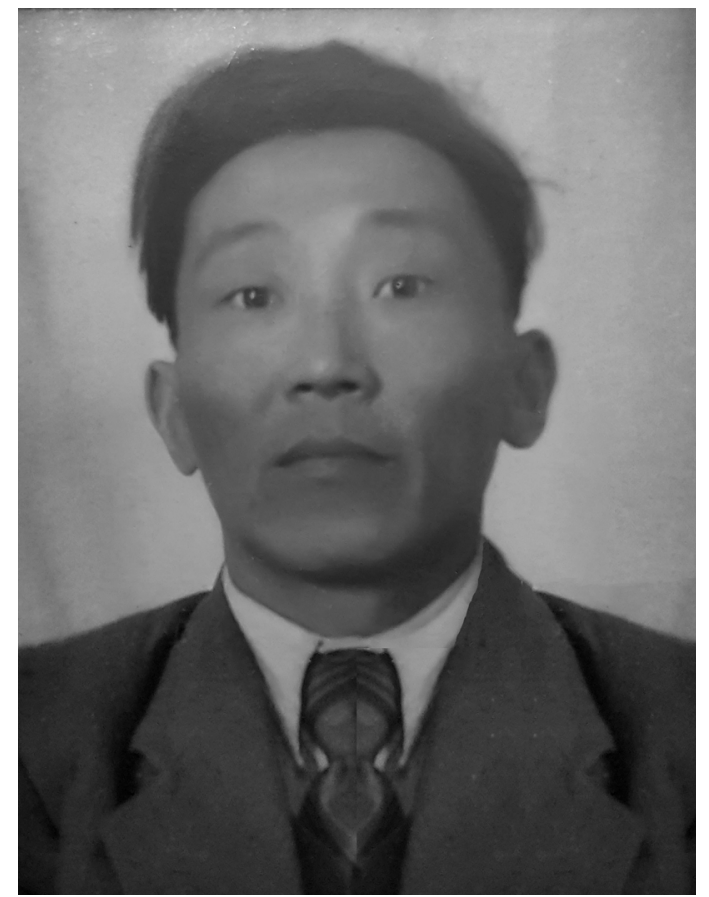

Фото 1. Сат Шангыр-оолович Мындрима, 1951 г. (ГА РТ, ф. n-2, On. 2, д. 1292, л. 3).

Photo 1. Sat Shangyr-oolovich Myndrima, 1951 (SA RT, f. П-2, op. 2, d. 1292, l. 3).

\section{Справка о С. Ш. Мындрима:}

«Мындрима Сат Шангролович родился в местечке Тоозуннуг сумона Урбюн Улуг-Хемского хошуна ТНР в декабре 1922 г. в семье арата-скотовода Сат Шангыр-оола. С 1932 по 1939 год учился в школе и медицинском техникуме при учебном комбинате им. Ленина в г. Кызыле. После окончания техникума с 1939 по 1943 год работал зав. медпунктами прииска Харал, сумона Кара-Холь БарунХемчикского хошуна и сумона Кызыл-Даг Чаа-Хольского хошуна. С декабря 1943 г. по июль 1948 г. работал инспектором Тувинского облздравотдела. С августа 1948 г. по сентябрь 1949 г. - редактором Тувинского облрадиокомитета. С сентября 1949 г. по август 1951 г. учился в Тувинской областной партийной школе. 1951-1965 гг. зав. партийным архивом Тувинского обкома КПСС» (ГА РТ, ф.-п. 2, оп. 2, д. 1292, л. 3).

Подобные справки есть на каждого руководителя. Каждый из них внес свой особенный вклад в развитие архивного дела в республике. На долю первого заведующего партархивом Тувинского обкома КПСС С.Ш. Мындрима выпали самые трудные организационные годы по приведению в порядок партийных фондов и других неупорядоченных материалов. Один из руководителей партийного архива К.Т.Аракчаа впоследствии занимался переводом многих документов ЦГА РТ со старомонгольского на тувинский язык (Саая, 2000: 21). Переводил архивные документы на тувинский язык и другой директор партиархива Санаа Шондаанович Баян (Баян, 2018: 4). Большая работа по приему в архив фондов личного происхождения была проделана Б.Д. Монгушем, одним из последних руководителей партийного архива. В личной беседе с держателями личных фондов, государственными и партийными деятелями он убежденно говорил о значимости их личных документов для истории республики и поэтому о необходимости их сдачи в партийный архив (Аньшина, 2000: 59).

Несмотря на имеющиеся трудности руководителям партархива при поддержке Тувинского обкома КПСС удалось наладить работу по хранению и сдаче документов партийных и комсомольских организаций и поставить работу по комплектованию фондов партийного архива на должный уровень. 


\section{Партийный архив в 1991-2017 22.}

До 1991 г. партийный архив комплектовался документами, поступающими из обкома партии, Кызылского горкома и райкомов КПСС, а также документами первичных партийных и комсомольских организаций, органов и учреждений. В связи с появлением с начала 1990-х гг. в республике новых общественных организаций и региональных отделений политических партий и в целях обогащения более полной, всесторонней и объективной информацией, свидетельствующей о коренных преобразованиях в общественно-политической и социально-экономической жизни Тувы архивохранилище стало комплектоваться документами разных партий и организаций негосударственной структуры (Чыдым, 2000: 11).

Прекращение деятельности КПСС в 1991 г. означало для всех бывших партийных архивов, вошедших в систему государственной архивной службы России, ликвидацию своих постоянных источников комплектования. Поэтому перед ними был выбор: стать некомплектующимся историческим архивом, или на принципиально новой основе и с новыми фондообразователями продолжить работу по комплектованию. В пользу второго варианта говорила настоятельная потребность максимально полного сохранения документации образовавшихся многочисленных общественных объединений. В 1991-1993 гг. отмечается активизация общественной жизни и в Туве. В Министерстве юстиции Республики Тыва было официально оформлено 48 общественных организаций, партий и движений.

Отношения между партийным архивом и общественными организациями строились на основе договоров. Негосударственные организации, как собственники документов, в соответствии с архивным законодательством, обладают всеми правами и распоряжениями, поэтому работа специалистов архива основывается только на разъяснении и убеждении, что документы общественных объединений представляют ценность для истории нашей республики (Сандак, 2008: 65). Поступавшие в архив документы общественно-политических организаций были разрозненны, часто отсутствовали даты, не указывались авторы. Работа по упорядочиванию документов, по экспертизе ценности ложилась на плечи самих архивистов (Михайлова, 2000: 56).

В соответствии с заключенными договорами приняты на постоянное хранение в архивохранилище бывшего партийного архива документы местных отделений таких общественно-политических организаций, как «Коммунистическая партия РФ», «Отечество», «Единство», «Российская народнореспубликанская партия», «Российский фонд мира», движения «Честь и Родина», «Народной партии суверенной Тувы», общественной организации «Общество тувинско-монгольской дружбы РТ», общественно-спортивной организации «Федерация национальной борьбы хуреш РТ» и ряда других организаций.

В соответствии с Указом Президента РСФСР Б. Ельцина от 24 августа 1991 г. № 83 «26 августа в автономные республики, края и области была отправлена телеграмма с поручением организовать передачу партархивов, текущих архивов рескомов, крайкомов, обкомов, горкомов и райкомов в ведение архивных органов вместе со зданиями, сооружениями, штатной численностью и фондом оплаты труда» (Тюнеев, 2011: 89). По распоряжению Председателя Совета Министров Республики Тува Ш. Ооржака от 2 сентября 1991 г. партийный архив Тувинского обкома КПСС передан Центральному государственному архиву Республики Тыва на правах архивохранилища (ГА РТ, ф. 270, оп. 1, д. 1469, л. 165). Все фонды, находившиеся в партийном архиве, были полностью переданы Центральному государственному архиву РТ по акту комиссии, созданной согласно Указу Президента РСФСР от 23 августа 1991 г. На момент передачи в архиве числилось 89120 ед. хр. по 350 фондам.

Передача бывших партархивов в 1991 г. в ведение государственной архивной службы обусловила необходимость проведения комплекса работ, обеспечивающих учет хранящихся документов на единой с государственными архивами организационно-методической основе. Интеграция учета документов и фондов бывшего партийного архива в систему государственного учета документов Архивного фонда Республики Тыва являлась одной из основных задач в Центре архивных документов партий и общественных организаций Центрального государственного архива РТ, так как учет документов бывшего партийного архива отличается от учета документов государственного архива.

Так, в партархиве учет велся по архивным фондам и единицам хранения. В состав основных учетных документов входила книга поступления, книга фондов, список фондов, описи дел, карточка фонда, дело фонда, паспорт архива. Такой порядок ведения этих учетных документов не в полной мере обеспечивал принцип пофондового учета дел. Комплекс основных учетных документов к каждому архивному фонду был неполным, отсутствовала методика их заполнения. 
Учет партийных фондов имел ряд и других особенностей. Запись об изменении объема фонда составлялась только суммарно, с нарастающим итогом и отмечалась в карточке фонда, а не по описям. В книге поступлений фиксировались объемы дел, поступивших от всех первичных партийных организаций того или иного партийного органа (горкома, райкома) общим количеством.

Таким образом, система учета не предусматривала заведения полного комплекса основных учетных документов на каждый фонд и не обеспечивала динамики изменений объемов дел по каждой описи. Дела фондов были заведены только на основные, более значимые фонды: «Тувинский обком КПСС», «ЦК ТНРП», «Кызыльский горком КПСС», «ЦК ТРСМ». Исторические справки составлялись тоже только на эти фонды. Центральный учет документов велся только на основании паспорта партийного архива. Не составлялись итоговые записи к «открытым описям» первичным партийных организаций; количество, включенных в них дел, учитывалось по последнему валовому номеру, что иногда не соответствовало действительности, потому что при нумерации могла быть допущена ошибка, например, пропущен номер, дело с литерными номерами.

Также в бывшем партийном архиве существовали и некоторые особенности систематизации дел, связанные с наличием в них множества описей и без единой валовой нумерации. В некоторых фондах насчитывалось по 10, 20, 40 и т. д. описей. Состав документов постоянного хранения был смешан в одной описи с документами по личному составу. Экземплярность описей не превышала двух. Сейчас эти описи усовершенствуются, составляются две описи: опись № 1 на дела постоянного срока хранения и опись № 2 по личному составу.

В описях дел партийного архива, в отличие от государственного архива, содержались дополнительные сведения о номере коробки, в которой хранится дело. После усовершенствования перешли на единую с государственным архивом форму описи. Каждая опись теперь имела итоговую запись, которая закрепляет количество дел, числящихся по описи, регистрирует особенности нумерации дел, отражает изменения в их количестве, произведенные на основе соответствующих актов (Болдур-оол, 2000: 48).

В 1998 г. архивохранилище № 2 ЦГА Республики Тыва приказом Председателя Государственной архивной службы РТ Д. И. Чыдым переименовано в Центр архивных документов партий и общественных организаций (ЦАДПОО) при ЦГА РТ (ГА РТ, ф. 12, оп. 1, д. 208, л. 1).

В эти годы началась активная работа по приему документов личного происхождения от политических, государственных деятелей, ученых, писателей, поэтов нашей республики. До 1998 г. в ЦАДПОО находился на хранении один личный фонд партийного и государственного деятеля, Героя социалистического труда, лауреата Государственной премии СССР, народного писателя Тувы - Салчака Калбакхорековича Тока (ГА РТ, ф.-п. 50). Как пишет в своей статье о С. К. Тока Григорий Чоодуевич Ширшин, именно в советский период, «в деле нового жизнеустройства тувинского народа в полной мере раскрылся его организаторский талант, как крупного руководителя и организатора народных масс» (Ширшин, 2017: 78).

Документы личного фонда С. К. Тока начали комплектовать с 1974 г. В деле фонда имеется акт, составленный 12 мая 1974 г. о том, что в Партийный архив Тувинского обкома КПСС были приняты документы, собранные работниками партархива, относящиеся к деятельности С. К. Тока за 1951-1971 гг. (частично за 1943, 1977 гг.) в количестве 50 дел. В настоящее время в данном фонде имеется 153 ед. хр. за 1930-1982 гг. Это документы о трудовой, творческой и общественной деятельности С. К. Тока. Большую часть фонда составляют: выступления и доклады С. К. Тока на конференциях, собраниях партактива и пленумах ЦК ТНРП и Тувинского обкома КПСС, на семинарах и совещаниях советских и хозяйственных работников, на съездах СССР, Верховного Совета СССР, Тувинской АССР, на пленумах ЦК КПСС, его переписка, статьи в газеты и журналы СССР и Тувинской АССР, а также поздравительные тексты и телеграммы по случаю знаменательных дат. На постоянном хранении в архиве находятся рукописи художественных произведений писателя с поправками, пометками автора: пьесы «Уур даргазынга уш чыл болдум» за 1937 г., «В берестяном чуме» за 1957 г., повести «Слово арата» за 1964 г.

С 1998 по 2017 г. на государственное хранение в ЦАДПОО поступили документы от 24 держателей личных фондов. Сформированы, например, личные фонды: министра внутренних дел Тувинской АССР Артаса Монгуша Баян-ооловича, министра просвещения Тувинской АССР Конгара Николая Салчаковича, Председателя Совета Министров Тувинской АССР Мендуме Михаила Клаевича, Ооржака Дандар-оола Кок-Хунаевича - секретаря Тувинского обкома КПСС, Председателя народного контроля Тувинской АССР, Председателя Палаты председателей Великого Хурала РТ. В составе этих фондов- 
автобиографии, рукописи, доклады, письма, фотографии, воспоминания и другие документы, отражающие социально-экономическую, общественно-политическую жизнь нашей республики. Поэтому они имеют большое историческое значение, в некоторых фондах имеются документы, представляющие особую историческую ценность и общекультурную значимость, уникальные документы (Оюн, 2008: 45).

Приказом № 20 директора Государственного архива РТ Б. В. Мунге от 15 июня 2017 г. в целях оптимизации структуры учреждения, вызванной производственной необходимостью и эффективностью использования трудовых ресурсов, с 1 июля 2017 г. структурное подразделение «Центр архивных документов партий и общественных организаций» (ЦАДПОО) переименован в «Отдел информационных технологий и исполнения социально-правовых запросов». Документы ЦАДПОО полностью перемещены в архивохранилище в здании Государственного архива Республики Тыва.

На момент ликвидации в ЦАДПОО на 1 июля 2017 г. числилось 396 фондов (97029 ед. хр.).

Работа по интеграции учета документов бывшего партийного архива продолжается. Ее конечным результатом должно стать создание современного, отвечающего потребностям пользователей научно-справочного аппарата к фондам партийных, комсомольских организаций, по принятым в государственных архивах правилам.

\section{Заключение}

Партийный архив Тувинского обкома КПСС является неотъемлемой частью истории архивного дела в Туве и истории республики. Он сыграл свою исключительную роль в развитии архивных служб государственных учреждений, в организации целенаправленной работы по сохранению документов КПСС, их обработке и систематизации. Партийный архив в полной мере выполнял функции, стоявшие перед ним, содействовал управлению в сфере документационного обеспечения, информационному обслуживанию органов государственной власти, организаций и граждан. Материалы фондов архива являлись источником научных исследований и трудов, выступая их доказательной базой.

В деятельности партийного архива Тувы выделяются три этапа, характеризующиеся качественными изменениями в организации его работы и комплектовании фондов: 1945-1960 гг., 1961-1991 гг., 1991-2017 гг. Имея общие принципы организации с другими архивами страны, партахив имел свои особенности и трудности, обусловленные историческим развитием республики. В его фондах хранились материалы на разных языках, на разных носителях, разного происхождения, качества и сохранности. Особое положение занимали документы на монгольском языке, так как они были исполнены на рисовой бумаге и требовали особых условий хранений, которые не предоставлялось возможным обеспечить.

Деятельность партийного архива Тувинского обкома КПСС и исторические документы, собранные в его фондах, имеют исключительно важное значение для истории Тувы советского периода, ее научного изучения, осмысления и анализа. Так, при подготовке III тома «Истории Тувы» были использованы уникальные материалы партийного архива (История Тувы, 2016: 455), что позволило рецензентам высоко оценить работу (Оплаканская, 2017). Том хронологически охватил 47-летний советский период (1944-1991 гг.), поэтому все его содержание пронизано ссылками на фонды бывшего партийного архива - Центра архивных документов партий и общественных организаций Государственного архива Республики Тыва (ЦАДПОО ГАРТ).

Особенно часто материалы архива использовались в разделах, посвященных политическим процессам в Туве: вхождение в состав СССР в октябре 1944 г., последующее преобразование Тувинской автономной области в Тувинскую АССР в 1961 г. Данные события влекли за собой реорганизацию общественно-политических и властных органов и сказывались на конституционно-правовом статусе Тувы.

Немало партийных документов было привлечено в томе при подготовке разделов, описывающих социальную сферу и духовную жизнь Тувы. Это во многом символично, так как коммунистическая партия особое внимание уделяла развитию образования, здравоохранения, науки и издательского дела, что нашло свое отражение в решениях, постановлениях и последующей строгой отчетности.

Материалы бывшего партийного архива Тувинского обкома КПСС содержат интереснейший комплекс документов по истории политической, социально-экономической, культурной сфер жизни республики. Несомненно, вновь освещенные факты послужат основой еще для многих исследований по истории Тувы. 


\section{СПИСОК ЛИТЕРАТУРЫ}

Аньшина, О. В. (2000) Из опыта работы по сбору документов личного происхождения // Доклады и сообщения секции «Архивы Республики Тыва - история государства и народа» международной конференции «Письменность: становление и развитие науки в Туве». 12-14 сентября 2000 г./ ред. коллегия:Д.И.Чыдым, Т.С. Саая, Т.А. Бондаренко, Т. Д. Монгуш. Кызыл: ЦГА РТ. 124 с. С. 57-59.

Аранчын, Ю. Л. (1955) Тува в годы Великой Отечественной войны Советского Союза. Кызыл : Тувинское книжное издательство. 68 с.

Баян, С. Ш. (2018) Шаги истории: от ревсомола к коммунизму / ред. Чооду К.-К. К., Хомушку А. В. Кызыл: ИП Саaя С. М. 100 c.

Болдур-оол, Н. Д. (2000) Интеграция учета документов бывших партийных архивов в систему государственного учета Архивного фонда Республики Тыва // Доклады и сообщения секции «Архивы Республики Тыва - история государства и народа» международной конференции «Письменность: становление и развитие науки в Туве». 12-14 сентября 2000 г. / ред. коллегия: Д. И. Чыдым, Т. С. Саая, Т. А. Бондаренко, Т. Д. Монгуш. Кызыл: ЦГА РТ. 124 с. C. 47-49.

Гущина, С. К. (2000) Документы бывших партийных организаций, как исторический источник их деятельности // Доклады и сообщения секции «Архивы Республики Тыва - история государства и народа» международной конференции «Письменность: становление и развитие науки в Туве». 12-14 сентября 2000 г. / ред. коллегия: Д. И. Чыдым, Т. С. Саая, Т. А. Бондаренко, Т. Д. Монгуш. Кызыл: ЦГА РТ. 124 с. С. 36-41.

Доклады и сообщения секции «Архивы Республики Тыва - история государства и народа» международной конференции «Письменность: становление и развитие науки в Туве». 12-14 сентября 2000 г. (2000) / редколл.: Д. И. Чыдым, Т. С. Саая, Т. А. Бондаренко, Т. Д. Монгуш. Кызыл: ЦГА РТ. 124 с.

Доржу, 3. Ю. (1979) Деятельность Тувинской организации КПСС по повышению социальной активности женщин в условиях развитого социализма : дисс. ... к-та и. н. Иркутск. 189 с.

История Тувы (2016): в 3 т. / под общ. ред. Н. М. Моллерова. Новосибирск : Наука. Т. III. 455 с.

Канзай, А. К. (2017) Партийные органы и общественные организации Тувинской народной республики в годы Великой Отечественной войны [Электронный ресурс] // Новые исследования Тувы. № 4. URL: https://nit.tuva.asia/ nit/article/view/737 (дата обращения: 14.01.2020.). DOI: 10.25178/nit.2017.4.2

Кенин-Лопсан, М. Б. (1982) Сюжеты и поэтика тувинского шаманства: (опыт ист.-этногр. реконструкции): автореф. дисс. ... канд. ист. наук. Л. 18 с.

Кенин-Лопсан, М. Б. (1996) Проблемы этнографического шаманизма: по материалам шаманского фольклора: автореф. дис. ... д-ра ист. наук. СПб. 53 с.

Материалы научно-практической конференции, посвященной 90-летию государственной архивной службы России. 29 мая 2008 г., Республика Тыва, г. Кызыл (2008) / отв. сост. Л. Д. Тажима и др.; ред. Р. М. Арчимаева. Кызыл: ГУП «Тываполиграф». 80 с.

Моллеров, Н. М. (1990) Русская самоуправляющаяся трудовая колония в ТНР и ее роль в укреплении тувинскосоветских отношений (1917-1932 гг.) : дисс. ... к. ист. н. Новосибирск. 25 с.

Моллеров, Н. М. (1989) Истоки братства. Русская самоуправляющаяся трудовая колония в Тувинской Народной Республике. Кызыл : Тувинское книжное издательство. 144 с.

Михайлова, Н. Е. (2000) Отбор и комплектование документов общественно-политических организаций // Доклады и сообщения секции «Архивы Республики Тыва - история государства и народа» международной конференции «Письменность: становление и развитие науки в Туве». 12-14 сентября 2000 г. / ред. коллегия: Д. И. Чыдым, Т. С. Саая, Т. А. Бондаренко, Т. Д. Монгуш. Кызыл: ЦГА РТ. 124 с. С. 53-56.

Мунге, Б. В. (2018) Становление и развитие архивного дела в Республике Тыва // Роль и значение архивов и архивных документов в сохранении исторической памяти народа: Материалы региональной научно-практической конференции, посвященной 100-летию государственной архивной службы России. 26 апр. 2018 г., Республика Тыва, г. Кызыл / отв. ред. Б. В. Мунге. Кызыл: Типография КЦО «Аныяк». 124 с. С. 5-9.

Ондар, Л. Ш. (1994) Социально-экономическое и культурное развитие Республики Тува в составе России, 1944-1993 гг. : дисс. .... к. и. н. М. 172 с.

Оплаканская, Р. В. (2017) История Тувы советского периода: проблемно, объективно, корректно [Электронный ресурс]//Новые исследования Тувы. № 4.URL: https://nit.tuva.asia/nit/article/view/742 (дата обращения: 14.01.2020.). DOI: $10.25178 /$ nit.2017.4.8

Очур, Н. М. (2017) Издательские проекты Тувинского института гуманитарных и прикладных социальноэкономических исследований 2016-2017 гг. [Электронный ресурс] // Новые исследования Тувы. № 4. URL: https:// nit.tuva.asia/nit/article/view/747 (дата обращения: 15.013.2020). DOI: https://www.doi.org/10.25178/nit.2017.4.14

Оюн, Д. Д. (2008) Архивные материалы ЦАДПОО ЦГА РТ - неотъемлемая часть истории Республики Тыва // Материалы научно-практической конференции, посвященной 90-летию государственной архивной службы 
России. 29 мая 2008 г., Республика Тыва, г. Кызыл / отв. сост. Тажима Л. Д. и др. Кызыл: ГУП «Тываполиграф». 80 с. C. $42-45$.

Правила работы партийных архивов обкомов, крайкомов партии, институтов истории партии - филиалов ИМЛ при ЦК КПСС (1980). М.: ИМЛ при ЦК КПСС. 120 с.

Саая, Т. С. (2000) Фонды Центрального государственного архива Республики Тыва - источники документальной истории республики // Доклады и сообщения секции «Архивы Республики Тыва - история государства и народа» международной конференции «Письменность: становление и развитие науки в Туве». 12-14 сентября 2000 г. / ред. коллегия: Д. И. Чыдым, Т. С. Саая, Т. А. Бондаренко, Т. Д. Монгуш. Кызыл: ЦГА РТ. 124 с. С. 15-22.

Сандак, Б. Ю. (2008) Общественные организации, их роль в комплектовании Архивного фонда Республики Тыва // Материалы научно-практической конференции, посвященной 90-летию государственной архивной службы России. 29 мая 2008 г., Республика Тыва, г. Кызыл / отв. сост. Тажима Л. Д. и др. Кызыл: ГУП «Тываполиграф». 80 c. C. $64-68$

Сейфуллин, Х. М. (1958) История Тувы. Краткий очерк. Кызыл: Тувинское книжное издательство. 384 с.

Толгар-оол, О. А. (1967) Образование и идейно-организационное укрепление Тувинской народно-революционной партии : автореф. дис. ... канд. ист. наук. Иркутск. 20 с.

Тюнеев, В. А. (2011) В августе 1991 года. О приеме партархивов в ведение государственных архивных органов // Отечественные архивы. № 3. С. 85-100.

Чыдым, Д. И. (2000) Архивная служба в Туве. История, состояние и перспективы развития // Доклады и сообщения секции «Архивы Республики Тыва - история государства и народа» международной конференции «Письменность: становление и развитие науки в Туве». 12-14 сентября 2000 г. / ред. коллегия: Д. И. Чыдым, Т. С. Саая, Т. А. Бондаренко, Т. Д. Монгуш. Кызыл : ЦГА РТ. 124 с. С. 5-15.

Ширшин, Г. Ч. (2017) Летопись советской Тувы 1950-1960-х гг. в дневниках Салчака Тока [Электронный ресурс] // Новые исследования Тувы. № 4. URL: https://nit. tuva.asia/nit/article/view/739 (дата обращения: 15.01.2020). DOI: https://www.doi.org/10.25178/nit.2017.4.4

Дата поступления: 01.02.2020 г.

\section{REFERENCES}

An'shina, O. V. (2000) Iz opyta raboty po sboru dokumentov lichnogo proiskhozhdeniia [From the experience of collecting documents of personal origin]. In: Doklady $i$ soobshcheniia sektsii "Arkhivy Respubliki Tyva - istoriia gosudarstva i naroda" mezhdunarodnoi konferentsii "Pis'mennost': stanovlenie i razvitie nauki v Tuve" [Reports and communications of the section "Archives of the Republic of Tuva - history of the state and people" at the International conference "Writing: formation and development of science in Tuva"]. September 12-14, 2000 / editorial board: D. I. Chydym, T. S. Saaia, T. A. Bondarenko and T. D. Mongush. Kyzyl, TsGA RT. 124 p. Pp. 57-59. (In Russ.).

Aranchyn, Yu. L. (1955) Tuva v gody Velikoi Otechestvennoi voiny Sovetskogo Soiuza [Tuva during the Great Patriotic War of the Soviet Union]. Kyzyl, Tuvan book publisher. 68 p. (In Russ.).

Baian, S. Sh. (2018) Shagi istorii: ot revsomola k kommunizmu [Steps of history: from revsomol to Communism] / ed. by Choodu K-K. K. and Khomushku A. V. Kyzyl, IP Saaia S. M. 100 p. (In Russ.).

Boldur-ool, N. D. (2000) Integratsiia ucheta dokumentov byvshikh partiinykh arkhivov v sistemu gosudarstvennogo ucheta Arkhivnogo fonda Respubliki Tyva [Integration of document management of former party archives into the system of state management of the archival collections of the Republic of Tuva]. In: Doklady $i$ soobshcheniia sektsii "Arkhivy Respubliki Tyva - istoriia gosudarstva i naroda" mezhdunarodnoi konferentsii "Pis'mennost': stanovlenie i razvitie nauki v Tuve" [Reports and communications of the section "Archives of the Republic of Tuva - history of the state and people" of the International conference "Writing: formation and development of science in Tuva"]. September 12-14, 2000 / editorial board: D. I. Chydym, T. S. Saaia, T. A. Bondarenko and T. D. Mongush. Kyzyl, TsGA RT. 124 p. Pp. 47-49. (In Russ.).

Gushchina, S. K. (2000) Dokumenty byvshikh partiinykh organizatsii, kak istoricheskii istochnik ikh deiatel'nosti. [Documents of ex-Communist Party local organizations as a historical source for studying the party's activity] In: Doklady i soobshcheniia sektsii "Arkhivy Respubliki Tyva - istoriia gosudarstva i naroda" mezhdunarodnoi konferentsii "Pis'mennost': stanovlenie i razvitie nauki v Tuve" [Reports and communications of the section "Archives of the Republic of Tuva - history of the state and people" of the International conference "Writing: formation and development of science in Tuva"]. September 12-14, 2000 / editorial board: D. I. Chydym, T. S. Saaia, T. A. Bondarenko and T. D. Mongush. Kyzyl, TsGA RT. 124 p. Pp. 36-41. (In Russ.).

Doklady i soobshcheniia sektsii "Arkhivy Respubliki Tyva - istoriia gosudarstva i naroda" mezhdunarodnoi konferentsii "Pis'mennost': stanovlenie i razvitie nauki v Tuve" [Reports and communications of the section "Archives of the Republic of Tuva - history of the state and people" of the International conference "Writing: formation and development of science in Tuva"]. September 12-14, 2000 / editorial board: D. I. Chydym, T. S. Saaia, T. A. Bondarenko and T. D. Mongush. Kyzyl, TsGA RT. 124 p. (In Russ.). 
Dorzhu, Z. Yu. (1979) Deiatel'nost' Tuvinskoi organizatsii KPSS po povysheniiu sotsial'noi aktivnosti zhenshchin v usloviiakh razvitogo sotsializma [Tuva organization of the CPSU and its work to increase the social activity of women in the conditions of developed socialism] : Diss.... Candidate of History. Irkutsk. 189 p. (In Russ.).

Istoriia Tuvy [The History Of Tuva] (2016): in 3 vols. / ed. by V. A. Lamin. Novosibirsk, Nauka. Vol. 3. 455 p. (In Russ.).

Kanzai, A. K. (2017) Partiinye organy i obshchestvennye organizatsii Tuvinskoi narodnoi respubliki v gody Velikoi Otechestvennoi voiny [Communist Party organs and non-governmental organizations in People's Republic of Tuva during the Great Patriotic War]. The New Research of Tuva, no. 4 [online] Available at: https://nit.tuva.asia/nit/article/view/737 (access date: 14.01.2020.). (In Russ.). DOI: https://doi.org/10.25178/nit.2017.4.2

Kenin-Lopsan, M. B. (1982) Siuzhety i poetika tuvinskogo shamanstva: (opyt ist.-etnogr. rekonstruktsii) [Narratives and poetics of Tuvan shamanism: an attempt at historical and ethnographic reconstruction]: Thesis of Diss. ... Candidate of History. Leningrad. 18 p. (In Russ.).

Kenin-Lopsan, M. B. (1996) Problemy etnograficheskogo shamanizma: po materialam shamanskogo fol'klora [Problems of ethnographic shamanism: according to the materials of shamanic folklore]: Thesis of Diss.... Doctor of History. St. Petersburg. 53 p. (In Russ.).

Materialy nauchno-prakticheskoi konferentsii, posviashchennoi 90-letiiu gosudarstvennoi arkhivnoi sluzhby Rossii. 29 maia 2008 g., Respublika Tyva, g. Kyzyl [Proceedings of the conference dedicated to the 90th anniversary of the state archival service of Russia. May 29, 2008, Republic of Tuva, Kyzyl] (2008) / comp. by L. D. Tazhima et al.; ed. by R. M. Archimaeva. Kyzyl, GUP «Tuvapoligraf». 80 p. (In Russ.).

Mollerov, N. M. (1990) Russkaia samoupravliaiushchaiasia trudovaia koloniia $v$ TNR $i$ ee rol' $v$ ukreplenii tuvinskosovetskikh otnoshenii (1917-1932 gg.) [The Russian self-governing labor colony in the TPR and its role in strengthening TuvanSoviet relations (1917-1932)] : Diss. ... Candidate of History. Novosibirsk. 25 p. (In Russ.).

Mollerov, H. M. (1989) Istoki bratstva. Russkaia samoupravliaiushchaiasia trudovaia koloniia v Tuvinskoi Narodnoi Respublike [The origins of the brotherhood. Russian self-governing labor colony in the Tuvan People's Republic]. Kyzyl, Tuvan book publisher. 144 p. (In Russ.).

Mikhailova, N. E. (2000) Otbor i komplektovanie dokumentov obshchestvenno-politicheskikh organizatsii [Selection and completion of documents of socio-political organizations]. In: Doklady i soobshcheniia sektsii "Arkhivy Respubliki Tyva - istoriia gosudarstva i naroda" mezhdunarodnoi konferentsii "Pis'mennost': stanovlenie i razvitie nauki v Tuve" [Reports and communications of the section "Archives of the Republic of Tuva - history of the state and people" of the International conference "Writing: formation and development of science in Tuva"]. September 12-14, 2000 / editorial board: D. I. Chydym, T. S. Saaia, T. A. Bondarenko and T. D. Mongush. Kyzyl, TsGA RT. 124 p. Pp. 53-56. (In Russ.).

Munge, B. V. (2018) Stanovlenie i razvitie arkhivnogo dela v Respublike Tyva [The Formation and development of archival business in the Republic of Tuva]. In: Rol' i znachenie arkhivov $i$ arkhivnykh dokumentov $v$ sokhranenii istoricheskoi pamiati naroda [The role and significance of archives and archival documents in preserving the historical memory of a people] : Proceedings of the regional conference dedicated to the 100th anniversary of the state archival service of Russia. April 26, 2018, Republic of Tuva, Kyzyl / ed. by B. V. Munge. Kyzyl, Tipografiia KTsO «Anyiak». 124 p. Pp. 5-9. (In Russ.).

Ondar, L. Sh. (1994) Sotsial'no-ekonomicheskoe i kul'turnoe razvitie Respubliki Tuva v sostave Rossii, 1944-1993 gg. [Socio-economic and cultural development of the Republic of Tuva in Russia, 1944-1993]: Diss.... Candidate of History. $172 \mathrm{p}$. (In Russ.).

Oplakanskaia, R. V. (2017) Istoriia Tuvy sovetskogo perioda: problemno, ob"ektivno, korrektno [History of Tuva in the Soviet period: a problem-based, objective and tactful approach]. The New Research of Tuva, no. 4 [online] Available at: https://nit.tuva.asia/nit/article/view/742 (access date: 14.01.2020.). (In Russ.). DOI: https://doi.org/10.25178/nit.2017.4.8

Ochur, N. M. (2017) Izdatel'skie proekty Tuvinskogo instituta gumanitarnykh i prikladnykh sotsial'no-ekonomicheskikh issledovanii 2016-2017 gg. [Editorial projects at Tuvan Institute for the humanities and applied social and economic studies, 2016-2017]. The New Research of Tuva, no. 4 [online] Available at: https://nit.tuva.asia/nit/article/view/747 (access date: 14.01.2020.). (In Russ.). DOI: https://doi.org/10.25178/nit.2017.4.14

Oiun, D. D. (2008) Arkhivnye materialy TsADPOO TsGA RT - neot'emlemaia chast' istorii Respubliki Tyva [Archival materials of TSADPOO TSGA RT-an integral part of the history of the Republic of Tuva]. In: Materialy nauchno-prakticheskoi konferentsii, posviashchennoi 90-letiiu gosudarstvennoi arkhivnoi sluzhby Rossii. 29 maia 2008 g., Respublika Tyva, g. Kyzyl [Proceedings of the conference dedicated to the 90th anniversary of the state archival service of Russia. May 29, 2008, Republic of Tuva, Kyzyl] / comp. by L. D. Tazhima et al. Kyzyl, GUP «Tyvapoligraf». 80 p. Pp. 42-45. (In Russ.).

Pravila raboty partiinykh arkhivov obkomov, kraikomov partii, institutov istorii partii - filialov IML pri TsK KPSS [Rules of work of party archives of regional committees, party regional committees, institutes of party history-branches of IML under the Central Committee of the CPSU] (1980). Moscow, IML pri TsK KPSS. 120 p. (In Russ.).

Saaia, T. S. (2000) Fondy Tsentral'nogo gosudarstvennogo arkhiva Respubliki Tyva - istochniki dokumental'noi istorii respubliki [Funds of the Central State Archives of the Republic of Tuva as sources of documentary history of the Republic]. In: Doklady i soobshcheniia sektsii "Arkhivy Respubliki Tyva - istoriia gosudarstva i naroda" mezhdunarodnoi konferentsii "Pis'mennost': stanovlenie i razvitie nauki v Tuve" [Reports and communications of the section "Archives of the Republic of 
Tuva - history of the state and people" of the International conference "Writing: formation and development of science in Tuva”]. September 12-14, 2000 / editorial board: D. I. Chydym, T. S. Saaia, T. A. Bondarenko and T. D. Mongush. Kyzyl, TsGA RT. 124 p. Pp. 15-22. (In Russ.).

Sandak, B. Yu. (2008) Obshchestvennye organizatsii, ikh rol'v komplektovanii Arkhivnogo fonda Respubliki Tyva [Public organizations, their role in expanding archival collections of the Republic of Tuva]. In: Materialy nauchno-prakticheskoi konferentsii, posviashchennoi 90-letiiu gosudarstvennoi arkhivnoi sluzhby Rossii. 29 maia 2008 g., Respublika Tyva, g. Kyzyl [Proceedings of the conference dedicated to the 90th anniversary of the state archival service of Russia. May 29, 2008, Republic of Tuva, Kyzyl] / comp. by L. D. Tazhima et al. Kyzyl, GUP «Tyvapoligraf». 80 p. Pp. 64-68. (In Russ.).

Seifullin, Kh. M. (1958) Istoriia Tuvy. Kratkii ocherk [History of Tuva: a brief essay]. Kyzyl, Tuvan book publisher. 384 p. (In Russ.).

Tolgar-ool, O. A. (1967) Obrazovanie i ideino-organizatsionnoe ukreplenie Tuvinskoi narodno-revoliutsionnoi partii [Creation and ideological and organizational strengthening of the Tuva People's Revolutionary Party]: Thesis of Diss. ... Candidate of History. Irkutsk. 20 p. (In Russ.).

Tiuneev, V. A. (2011) V avguste 1991 goda. O prieme partarkhivov v vedenie gosudarstvennykh arkhivnykh organov [In August of 1991. On the admission of party archives to the state archival authorities]. Otechestvennye arkhivy, no. 3, pp. 85-100. (In Russ.).

Chydym, D. I. (2000) Arkhivnaia sluzhba v Tuve. Istoriia, sostoianie i perspektivy razvitiia [Archive service in Tuva. History, state and prospects of development]. In:Dokladyi soobshcheniia sektsii "ArkhivyRespubliki Tyva-istoriiagosudarstva i naroda" mezhdunarodnoi konferentsii "Pis'mennost': stanovlenie i razvitie nauki v Tuve" [Reports and communications of the section "Archives of the Republic of Tuva - history of the state and people" of the International conference "Writing: formation and development of science in Tuva"]. September 12-14, 2000 / editorial board: D. I. Chydym, T. S. Saaia, T. A. Bondarenko and T. D. Mongush. Kyzyl, TsGA RT. 124 p. Pp. 5-15. (In Russ.).

Shirshin, G. Ch. (2017) Letopis' sovetskoi Tuvy 1950-1960-kh gg. v dnevnikakh Salchaka Toka [A chronicle of the Soviet Tuva (1950s - 1960s) in the diaries of Salchak Toka]. The New Research of Tuva, no. 4 [online] Available at: https://nit.tuva. asia/nit/article/view/739 (access date: 15.01.2020). (In Russ.). DOI: https://doi.org/10.25178/nit.2017.4.4 